\title{
Design, Usage and Impact of Virtual University Mobile LMS Application on Students Learning of Virtual University of Pakistan
}

\author{
${ }^{1}$ Masroor Ahmed ${ }^{2}$ Dr. Shahid Minhas \\ ${ }^{1}$ Lecturer, Mass Communication, Virtual University of Pakistan \\ ${ }^{2}$ Assistant Professor, Department of Mass Communication/Media Studies, \\ GIFT University Gujranwala, Punjab Pakistan
}

\begin{abstract}
Information, communication, and technological developments had a profound impact on various fields including education. This change has enabled a transition from traditional system of education to distance learning or blended education. The key component of distance learning is its Learning Management System (LMS) that is both available in web-based and mobile application form. This study has focused on the use of mobile LMS application in the context of distance learning education environment. In this work, the student satisfaction with the design, its usage and impact on students learning at Virtual University of Pakistan is investigated. Through a structured questionnaire, a survey from a sample of 200 respondents was conducted to carry out this study. The findings indicate that students are satisfied with the design of the LMS application; they use it frequently to access their courses information and agree that the application has enhanced their learning. Valuable suggestions and recommendations have been given by students for further improvement of the VU mobile LMS application.
\end{abstract}

Key words: design, usage, impact, students learning, VU Mobile LMS application.

\section{INTRODUCTION}

The computer and the internet technology have encouraged the higher education to shift towards elearning mode [1]. E-learning uses the information and communication technology to enhance learning and education [2]. E-learning reduces the gap between the students in two different geographical locations. Moreover, E learning provides an easy access to learning content and administration. In e-learning system, students share material and interact online through a web-based system known as LMS [3].

In recent few years, the e-learning modes of education have attracted a lot of student's across the world due to its low cost and ease of learning. In Pakistan, apart from Virtual University of Pakistan (VUP) many other higher institutes have also started offering distance learning programs including International Islamic university Islamabad (IIUI, Islamia University of Bahawalpur (IUB), University of Peshawar, Gomal
University, Allama Iqbal open University (AIOU) etc. For this purpose, they have developed online LMSs to support students learning. However, the most updated and mature LMS system is used in VUP that was incepted in March, 2002. VU LMS offers services to students as video lessons, Handouts, Lesson overview, Announcement section, Moderated discussion board, Graded discussion board, assignment and Quiz section etc.

To further support student learning, Virtual University of Pakistan launched the VULMS Mobile Android App for its students on $14^{\text {th }}$ August. The application has been designed to facilitate students to receive push notifications, course announcements, fee alerts, videos and discussions. Due to this application, students remain synchronized and updated with their day to day learning and academic activities.

This work discusses the descriptive analysis of the survey conducted among students of Virtual University of Pakistan to identify the student's satisfaction with the design, usage and the impact of VU Mobile Application on the students' learning.

\subsection{Purpose of the study}

The research was aimed at exploring student's perception pertaining to the design, use and impact of VU Mobile LMS application on students' learning.

\subsection{Research objectives}

1. To explore the usage of VU Mobile LMS application among students at VUP.

2. To investigate the impact of VU Mobile LMS application on students learning at VUP.

3. To understand the students perspective about VU Mobile LMS application.

4. To explore the limitations of VU Mobile LMS application.

\section{LITERATURE REVIEW}

The 7 billion active subscribers of mobile phones highlight the potential of mobile learning and its use for education purpose [4]. The revolution in Information and communication technologies (ICTs) has changed the concept of traditional classrooms. The phenomena of virtual learning is not new to people. Due to the increased 
usage of internet, even mobile phones are frequently used in the third world countries to access available information [5].

Access to education is a major issue in the developing world, especially access to higher education according [6]. This is due to the unavailability of resources and shortage of qualified staff. Considering the emerging teaching skills, teachers are excited to come up with innovative teaching ideas and means of delivery to effectively impart knowledge [7]. [8] found that, there has been an increased demand for the use of technology and electronic learning system in higher education. Due to its use, people learn effectively and impact teaching also. Thus, to support and create an interactive and conducive learning environment (online) appropriate technology tools should be used [9].

In the distance learning context, the software which allows instructors to manage assignments, distribution, communication and other activity related to the courses in termed as LMS. The four basic elements of distance learning system include content, users, software or the LMS [10]. A mobile application in terms of its usability, user preference is important to know the quality of the application. They prefer a mobile application that are less time when doing a task, easy to learn and easy to use [11]. [12] The launches of mobile learning become important tool of teaching and learning. The maturity of mobile technology has supported learning activities in daily lives students are surrounded by it. Also, the wireless technology has provided easy access to the educational content without being bound to any location [13]. This has enabled timely and active spread of knowledge.

As per [14] stressed that, there is a need that instructors should ensure a comfortable mobile learning environment. A study by [15] explored that there is a positive influence of the use of mobile LMs on the academic achievement of students. According to a conclusion drawn by [16] the use of application developed for university courses is highly appreciated by students that supports and enhance their learning, also establishing their collaboration with teachers. Thus, is has been recommended that new innovative ideas to be poured in by universities to support both face-to-face and formalinformal learning. Majority of the university students uses mobile applications for study purpose as well [17], WhatsApp is also a major social media App used by the university students in their peer group for group study and communicate study material, however, this App was also used for social interaction the study noted. Due to uncertain situation, the higher institutions also need to adopt E-learning, for the purpose to save students time and continue their studies without any interruption [18].

Higher education institution use Google class room and Zoom video conferencing App for the Elearning which were very effective according to [19], students felt easy to use these Apps and LMS and expressed that they find it very easy to use and effective. Teachers and other supporting staff noted these Apps as effective and easy to use for E-learning as LMS.

\section{RESEARCH METHODOLOGY}

It is a quantitative study in which the three aspects on VU Mobile LMS application have been studied i.e. design, usage and impact. Survey methodology had been used in this study. The population of this study was the students of VUP and a sample of 200 students was selected through purposive sampling technique. For this purpose, an online link containing a structured questionnaire was sent to students in various campuses of VUP. Moreover, the link was also shared with VUP students at different online forum. A descriptive analysis of the gathered data has been carried out.

\section{DATA ANALYSIS}

\begin{tabular}{|c|c|c|c|c|c|c|}
\hline $\begin{array}{l}\text { Sr } \\
\#\end{array}$ & Questions & S A & $\mathbf{A}$ & $\mathbf{N}$ & D & SD \\
\hline 1. & $\begin{array}{l}\text { The language } \\
\text { used in } \\
\text { VU Mobile } \\
\text { LMS App is } \\
\text { easily } \\
\text { Understandable. }\end{array}$ & $\begin{array}{l}71 \\
(35.5 \%)\end{array}$ & $\begin{array}{l}106 \\
(53 \%)\end{array}$ & $\begin{array}{l}22 \\
(11 \%)\end{array}$ & $\begin{array}{l}1 \\
(.5 \%)\end{array}$ & 0 \\
\hline 2. & $\begin{array}{l}\text { The links given } \\
\text { on the VU } \\
\text { Mobile LMS } \\
\text { App are easily } \\
\text { accessible. }\end{array}$ & $\begin{array}{l}81 \\
(40.5 \%)\end{array}$ & $\begin{array}{l}105 \\
(52.5 \%\end{array}$ & $\begin{array}{l}14 \\
(7 \%)\end{array}$ & 0 & 0 \\
\hline 3. & $\begin{array}{l}\text { Navigation } \\
\text { buttons of VU } \\
\text { Mobile LMS } \\
\text { App are easily } \\
\text { clickable }\end{array}$ & $\begin{array}{l}69 \\
(34.5 \%)\end{array}$ & $\begin{array}{l}101 \\
(50.5 \%\end{array}$ & $\begin{array}{l}20 \\
(10 \%)\end{array}$ & $\begin{array}{l}10 \\
(5 \%)\end{array}$ & 0 \\
\hline 4. & $\begin{array}{l}\text { The layout of } \\
\text { the VU Mobile } \\
\text { LMS App is } \\
\text { Good. }\end{array}$ & $\begin{array}{l}77 \\
(38.5 \%)\end{array}$ & $\begin{array}{l}73 \\
(36.5 \%\end{array}$ & $\begin{array}{l}24 \\
(12 \%)\end{array}$ & $\begin{array}{l}19 \\
(9.5 \%)\end{array}$ & $\begin{array}{l}7 \\
(3.5 \%\end{array}$ \\
\hline 5. & $\begin{array}{l}\text { I am satisfied } \\
\text { with the } \\
\text { available } \\
\text { content on the } \\
\text { VU Mobile } \\
\text { LMS App. }\end{array}$ & $\begin{array}{l}72 \\
(36 \%)\end{array}$ & $\begin{array}{l}99 \\
(49.5 \%)\end{array}$ & $\begin{array}{l}7 \\
(3.5 \%)\end{array}$ & $\begin{array}{l}17 \\
(8.5 \%)\end{array}$ & $\begin{array}{l}5 \\
(2.5 \%\end{array}$ \\
\hline 6. & $\begin{array}{l}\text { VU Mobile } \\
\text { LMS App is } \\
\text { user friendly. }\end{array}$ & $\begin{array}{l}76 \\
(38 \%)\end{array}$ & $\begin{array}{l}88 \\
(44 \%)\end{array}$ & $\begin{array}{l}23 \\
(11.5 \%)\end{array}$ & $\begin{array}{l}13 \\
(6.5 \%)\end{array}$ & 0 \\
\hline
\end{tabular}

Table 1. Design of LMS Mobile App

SA: Strongly Agree, A: Agree, N: Neutral

D: Disagree, SD: Strongly Disagree

The table 1 shows that $53 \%$ of the respondents agree that the language used in the LMS mobile application is easily understandable. 52\% agree that the links given on the VU Mobile LMS App are easily accessible. $50.5 \%$ agreed that Navigation buttons of VU Mobile LMS App are easily clickable. 38.5\% agreed that the layout of the VU Mobile LMS App is good while 36\% agreed to this question. $49.5 \%$ agreed that they are satisfied with the available content on the VU Mobile LMS App. $44 \%$ of the respondents agreed that VU Mobile LMS App is user friendly. 


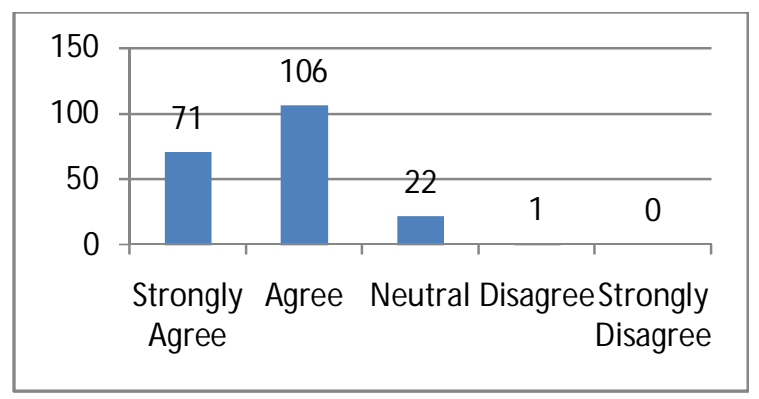

Figure 4.1: The language used in VU Mobile LMS App is easily understandable.

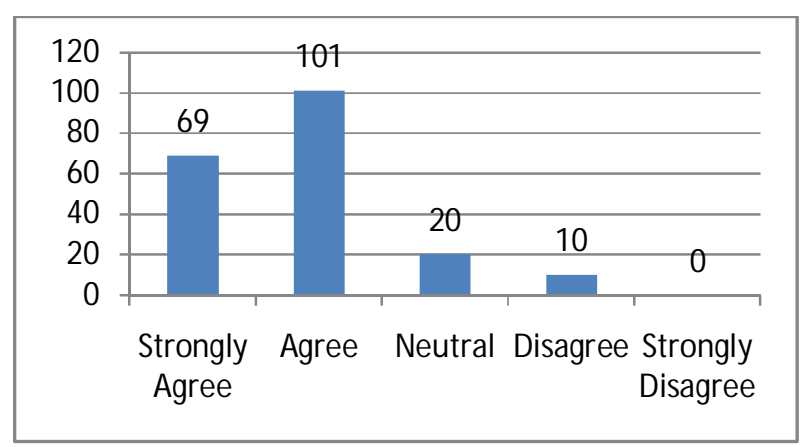

Figure 4.2: Navigation buttons of VU Mobile LMS App are easily Clickable.

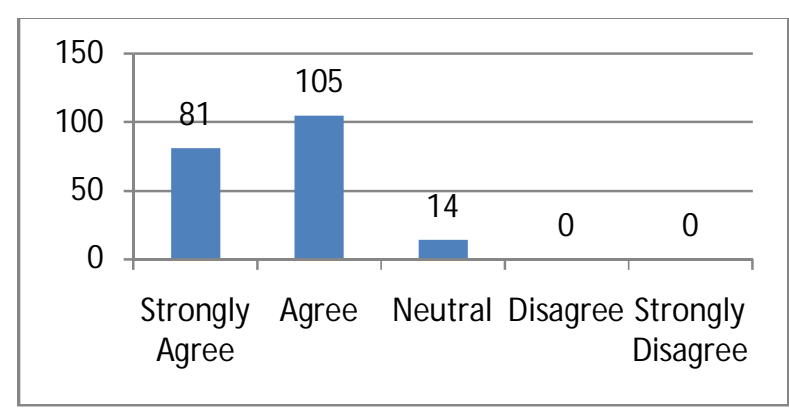

Figure 4.3: The links given on the VU Mobile LMS App are easily accessible.

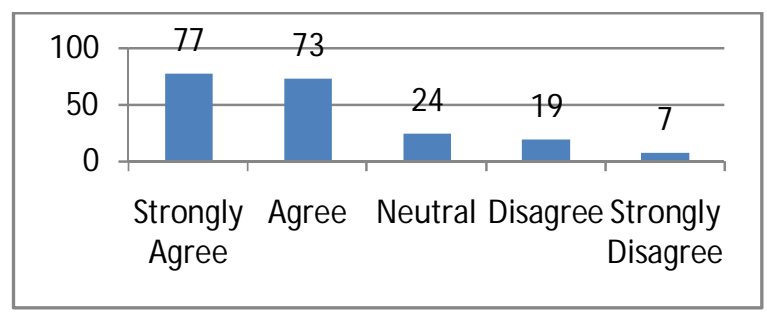

Figure 4.1: The layout of the VU Mobile LMS App is Good.

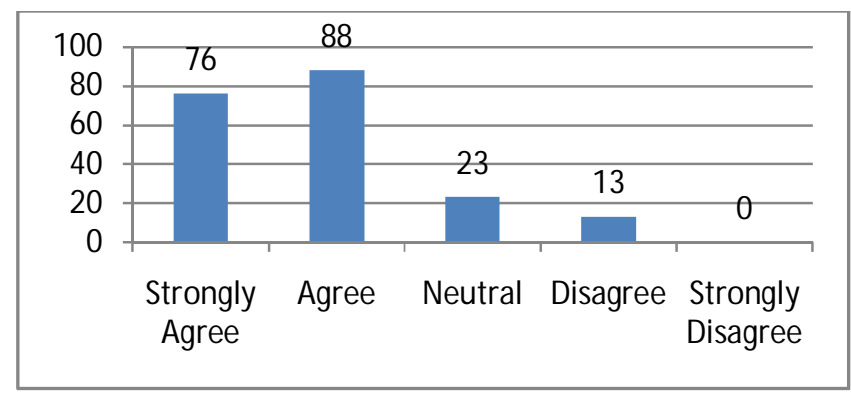

Figure 4.2:VU Mobile LMS App is User Friendly

\begin{tabular}{|c|c|c|c|c|c|c|c|}
\hline \multirow[b]{2}{*}{ Item } & \multicolumn{7}{|l|}{ Frequency } \\
\hline & & D & $\begin{array}{l}\text { ST } \\
\text { W }\end{array}$ & $\mathbf{W}$ & $\mathbf{M}$ & $\begin{array}{l}\text { OP } \\
\mathbf{S}\end{array}$ & $\mathbf{N}$ \\
\hline $\begin{array}{l}\text { Logi } \\
n\end{array}$ & $\begin{array}{lc}\text { Login } & \text { to VU } \\
\text { LMS } & \text { Mobile } \\
\text { App. } & \\
\end{array}$ & $\begin{array}{l}111 \\
(55.5 \\
\%)\end{array}$ & $\begin{array}{l}77 \\
(38.5 \\
\%)\end{array}$ & $\begin{array}{l}12 \\
(25.2 \\
5 \%)\end{array}$ & 0 & 0 & 0 \\
\hline \multirow[t]{3}{*}{$\begin{array}{l}\text { Cou } \\
\text { rse }\end{array}$} & $\begin{array}{l}\text { Check for an } \\
\text { assignment, } \\
\text { Quiz and GDB } \\
\text { Announcement. }\end{array}$ & $\begin{array}{l}32 \\
(16 \% \\
)\end{array}$ & $\begin{array}{l}19 \\
(9.5 \\
\%)\end{array}$ & $\begin{array}{l}67 \\
(33.5 \\
\%)\end{array}$ & $\begin{array}{l}82 \\
(41 \% \\
)\end{array}$ & 0 & 0 \\
\hline & $\begin{array}{l}\text { Check for } \\
\text { students MDBs } \\
\text { on MDB and } \\
\text { teacher } \\
\text { comments. }\end{array}$ & $\begin{array}{l}107 \\
(53.5 \\
\%)\end{array}$ & $\begin{array}{l}73 \\
(36.5 \\
\%)\end{array}$ & $\begin{array}{l}19 \\
(9.5 \\
\%)\end{array}$ & $\begin{array}{l}1 \\
(.5 \%)\end{array}$ & 0 & 0 \\
\hline & $\begin{array}{l}\text { Watch video } \\
\text { lessons. }\end{array}$ & $\begin{array}{l}63 \\
(31.5 \\
\%)\end{array}$ & $\begin{array}{l}51 \\
(25.5 \\
\%)\end{array}$ & $\begin{array}{l}69 \\
(34.5 \\
\%)\end{array}$ & $\begin{array}{l}17 \\
(8.5 \\
\%)\end{array}$ & 0 & 0 \\
\hline $\begin{array}{l}\text { Noti } \\
\text { ce } \\
\text { Boa } \\
\text { rd }\end{array}$ & $\begin{array}{l}\text { Check updates } \\
\text { and other } \\
\text { announcements }\end{array}$ & $\begin{array}{l}68 \\
(34 \% \\
)\end{array}$ & $\begin{array}{l}53 \\
(26.5 \\
\%)\end{array}$ & $\begin{array}{l}70 \\
(35 \% \\
)\end{array}$ & $\begin{array}{l}9 \\
(4.5 \\
\%)\end{array}$ & 0 & 0 \\
\hline \multirow[t]{3}{*}{$\begin{array}{l}\text { Res } \\
\text { ults }\end{array}$} & $\begin{array}{ll}\text { Check for } & \text { for } \\
\text { Assignment } & \\
\text { results. } & \end{array}$ & $\begin{array}{l}3 \\
(1.5 \\
\%)\end{array}$ & $\begin{array}{l}7 \\
(3.5 \\
\%)\end{array}$ & $\begin{array}{l}21 \\
(10.5 \\
\%)\end{array}$ & $\begin{array}{l}189 \\
(94.5 \\
\%)\end{array}$ & 0 & 0 \\
\hline & $\begin{array}{l}\text { Check for Quiz } \\
\text { results. }\end{array}$ & 0 & 0 & $\begin{array}{l}7 \\
(4.5 \\
\%)\end{array}$ & $\begin{array}{l}193 \\
(96.5 \\
\%\end{array}$ & 0 & 0 \\
\hline & $\begin{array}{l}\text { Check for GDB } \\
\text { results. }\end{array}$ & 0 & 0 & 0 & $\begin{array}{l}55 \\
(27.5 \\
\%\end{array}$ & $\begin{array}{l}145 \\
(72 . \\
5 \%)\end{array}$ & 0 \\
\hline
\end{tabular}

Table 2. Usage of VU Mobile App

D: Daily, STW: Several Times per Week, W: Weekly, M: Monthly, OPS: Once per Semester, N: Never

In table 2, the respondents said that they daily $\operatorname{login}(55.5 \%)$ to VU LMS Mobile application. 16\% Check for an assignment, Quiz and GDB Announcement on daily basis $33.5 \%$ weekly and $41 \%$ on monthly basis. $53.5 \%$ Check for students MDBs on MDB and teacher comments on daily basis and $36.5 \%$ several times per week. Students watch video lessons $34.5 \%$ on weekly basis, $31.5 \%$ on daily basis and $25.5 \%$ several times per week. $34 \%$ Check updates and other announcements on daily basis and $35 \%$ on weekly basis. $94.5 \%$ of the respondents check for Assignment results on monthly basis. $72.5 \%$ Check for GDB results once per semester. 


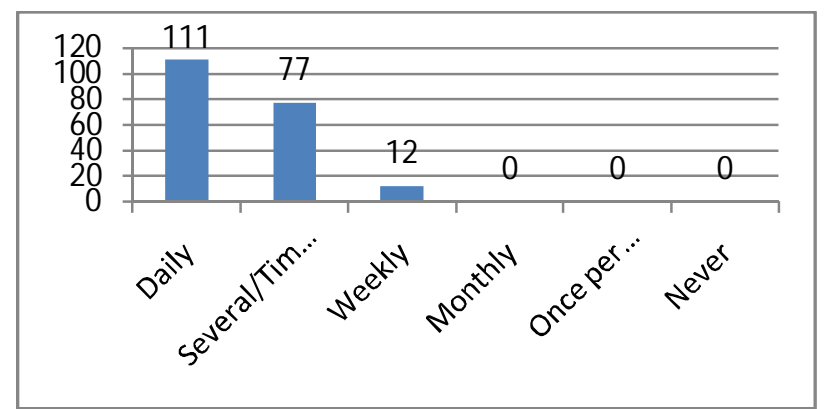

Figure 4.3:Login

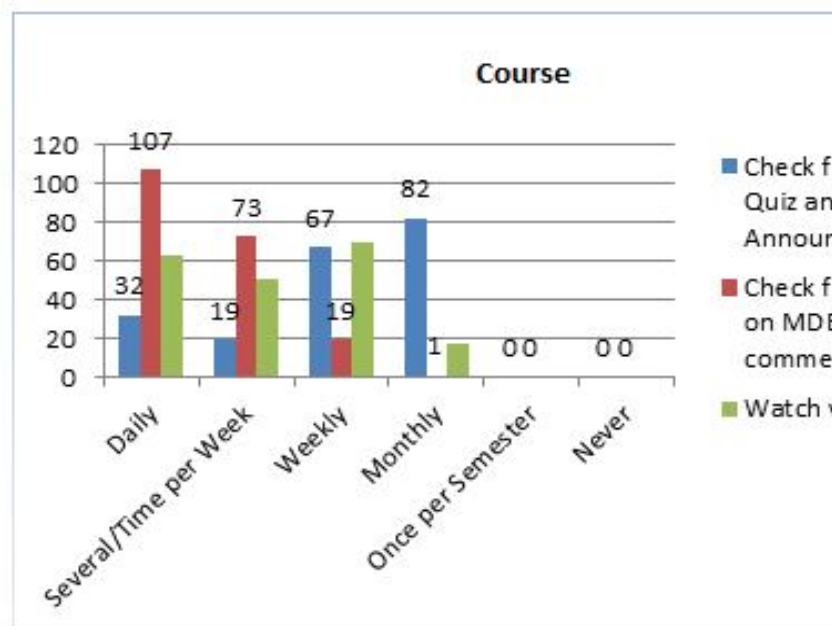

Figure 4.4: Course

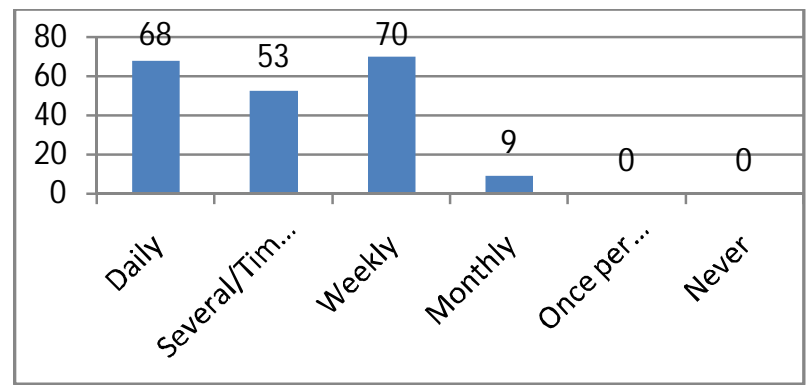

Figure 4.5: Check Updates and Other Announcements

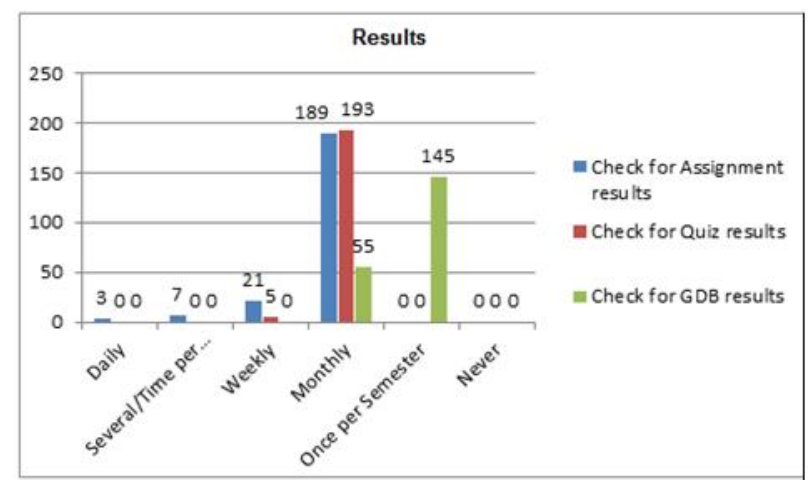

Figure 4.6: Results

\begin{tabular}{|c|c|c|c|c|c|c|}
\hline $\begin{array}{l}\text { S/N } \\
\text { o. }\end{array}$ & Questions & SA & $\overline{\mathbf{A}}$ & $\mathbf{N}$ & D & SD \\
\hline 1. & $\begin{array}{l}\text { I can easily } \\
\text { post an } \\
\text { MDB, } \\
\text { through } \\
\text { VU LMS } \\
\text { Mobile } \\
\text { App. }\end{array}$ & $\begin{array}{l}143 \\
(71.5 \\
\%)\end{array}$ & $\begin{array}{l}48 \\
(24 \% \\
)\end{array}$ & 0 & $\begin{array}{l}9 \\
(4.5 \\
\%)\end{array}$ & 0 \\
\hline 2. & $\begin{array}{l}\text { Compare to } \\
\text { web LMS, } \\
\text { VU LMS } \\
\text { Mobile } \\
\text { App } \\
\text { Provide } \\
\text { easy access } \\
\text { to my } \\
\text { courses. }\end{array}$ & $\begin{array}{l}177 \\
(88.5 \\
\%)\end{array}$ & $\begin{array}{l}20 \\
(10 \% \\
)\end{array}$ & $\begin{array}{l}3 \\
(1.5 \\
\%)\end{array}$ & 0 & 0 \\
\hline 3. & $\begin{array}{l}\text { VU LMS } \\
\text { Mobile } \\
\text { App gives a } \\
\text { Pop up } \\
\text { message of } \\
\text { any } \\
\text { Assignment } \\
\text { Quiz and } \\
\text { GDB } \\
\text { announcem } \\
\text { ent. }\end{array}$ & $\begin{array}{l}33 \\
(16.5 \\
\%)\end{array}$ & $\begin{array}{l}49 \\
(24.5 \\
\%)\end{array}$ & $\begin{array}{l}82 \\
(41 \\
\%)\end{array}$ & $\begin{array}{l}23 \\
(11.5 \\
\%)\end{array}$ & $\begin{array}{l}13 \\
(6.5 \\
\%)\end{array}$ \\
\hline 4. & $\begin{array}{l}\text { I watch } \\
\text { video } \\
\text { lessons } \\
\text { without the } \\
\text { need of a } \\
\text { laptop/com } \\
\text { puter, } \\
\text { through } \\
\text { VU LMS } \\
\text { Mobile } \\
\text { App. }\end{array}$ & $\begin{array}{l}167 \\
(83.5 \\
\%)\end{array}$ & $\begin{array}{l}30 \\
(15 \% \\
)\end{array}$ & $\begin{array}{l}7 \\
(3.5 \\
\%)\end{array}$ & 0 & 0 \\
\hline 5. & $\begin{array}{l}\text { Overall, I } \\
\text { feel VU } \\
\text { LMS } \\
\text { Mobile } \\
\text { App } \\
\text { enhances } \\
\text { my } \\
\text { learning. }\end{array}$ & $\begin{array}{l}180 \\
(90 \% \\
)\end{array}$ & $\begin{array}{l}20 \\
(10 \% \\
)\end{array}$ & 0 & 0 & 0 \\
\hline
\end{tabular}

Table 3. The Impact of VU Mobile App towards Student Learning

SA: Strongly Agree, A: Agree, N: Neutral,

D: Disagree, SD: Strongly Disagree

In table $3,(71.5 \%)$ of the respondents strongly agreed that they can easily post an MDB through the VU LMS Mobile application. (88.5\%) Strongly agree that, as compared to web LMS, VU LMS Mobile application provide easy access to their courses. Regarding the VU LMS Mobile App pop up service to any Assignment, Quiz and GDB announcement, they shown a $(41 \%)$ neutral stance and agreed $(24.5 \%)$. They strongly agreed that 
$(83.5 \%)$ watch video lessons without the need of a laptop/computer, through VU LMS Mobile App while (90\%) feel that overall, VU LMS Mobile App enhances my learning.

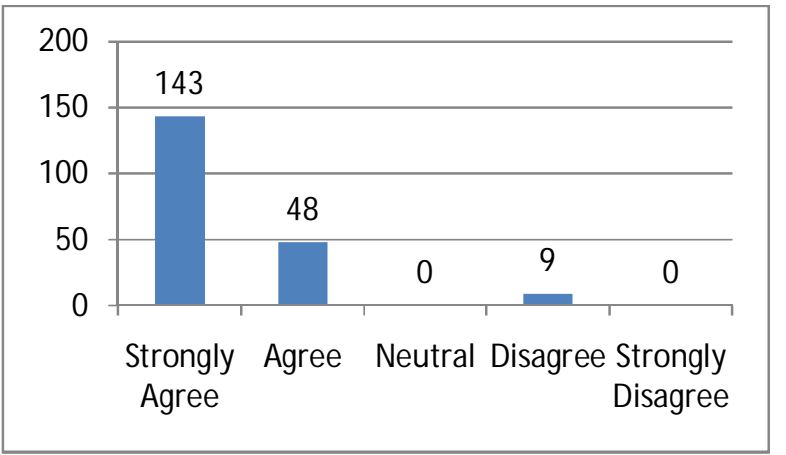

Figure 4.7:I can easily post an MDB, through VU LMS Mobile App.

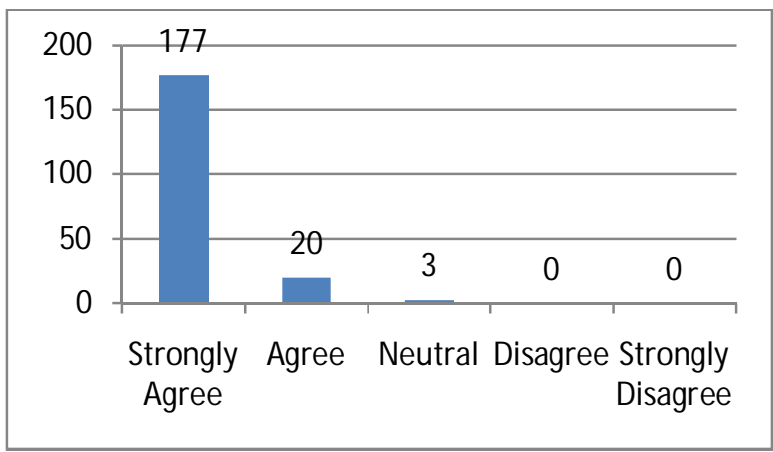

Figure 4.8: Compare to web LMS, VU LMS Mobile AppProvide easy access to my courses.

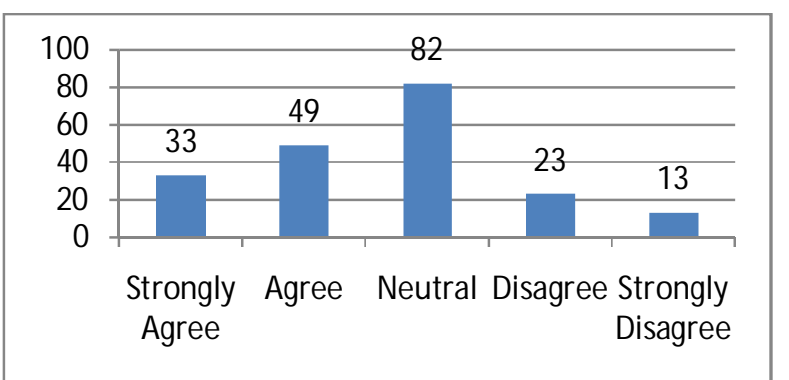

Figure 4.9: VU LMS Mobile App gives a prompt message of any Assignment, Quiz and GDB announcement.

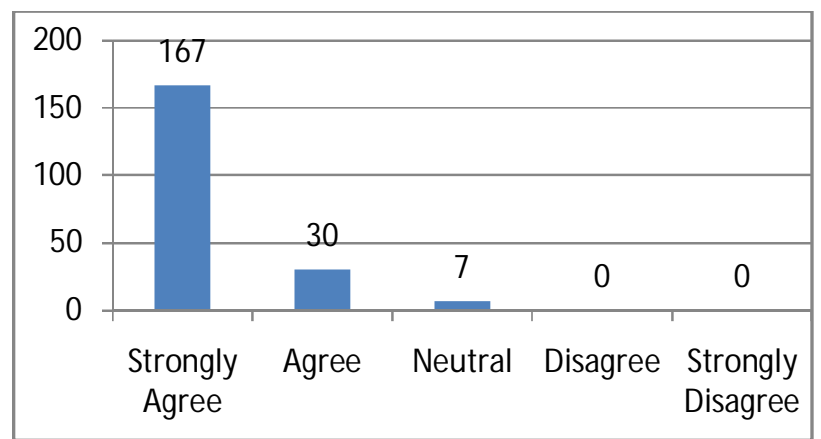

Figure 4.10:I watch video lessons without the need of a laptop/computer, through VU LMS Mobile App.

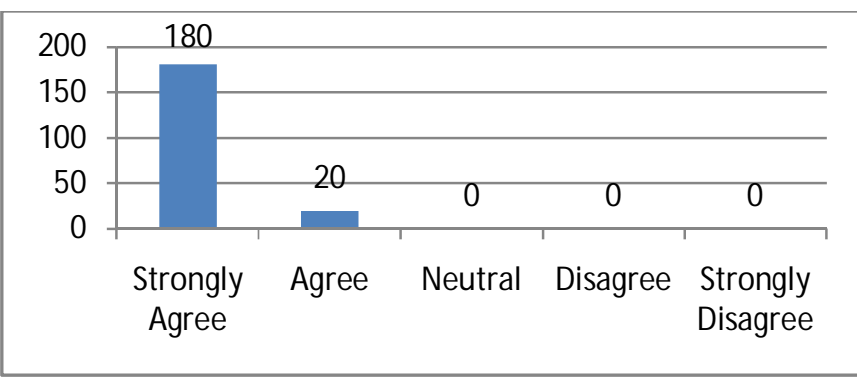

Figure 4.11: Overall, I feel VU LMS Mobile App enhances my learning.

\section{DISCUSSION}

The results of the study indicate that students are satisfied with the design of the VU mobile LMS application. They use it frequently to access their courses and get the required information instantly. They find it an easy way to navigate through the application to access course material and watch video lessons. They feel satisfied that the language used in the application is easy to understand. Results also show that, 111 (55.5\%) of the respondents agree that through this application they get instant updates related to their graded activities such as assignment, quiz and GDB announcements. Apart from these, they can access notice board with news and updates of the university. Mobile LMS application is important in saving time of student and making learning more convenient.

Virtual University is thus striving to provide multiple ways to students to access their courses and for easy learning. E-learning provides convenience and portability as students can access it anywhere i.e. at home, at work or while in transit. The result support the study other related studies on the same point affirmed that students prefer mobile learning apps than LMS for accessing their courses. The results also confirmed that the students are strongly agreed on the role of enhancing of learning through VU LMS Mobile App while other are agreed pertaining to the role of enhancing of learning of students. It is also important to mention here that no students showed disagreement with VU LMS Mobile App in enhancing of learning. Meanwhile the results illustrates 167 numbers of students are strongly agreed watching video lessons without the need of a laptop/computer.

The results also illustrates that 80 of the student showed neutral stance on the VU LMS Mobile App that it gives a prompt message of any Assignment, Quiz and GDB announcement, also 49 number of student agreed with the statement mentioned above while there are 13 students who are strongly disagree with the role of VU LMS Mobile App in giving a prompt message of any Assignment, Quiz and GDB announcement. Here it is important to mention here that at least 33 students are strongly agreed with the statement that VU LMS Mobile App gives a prompt message of any Assignment, Quiz and GDB announcement.

If we talk about the Design of LMS Mobile App the results are very clear with indication that $35.5 \%$ of students are strongly agreed that the language used in VU 
Mobile LMS App is easily understandable, 53\% are showed agreement only, $11 \%$ are neutral, $0.5 \%$ are disagree with the question however it important that $0 \%$ of students strongly disagree with the question asked that the language used in VU Mobile LMS App is easily understandable. The results showed that $40.5 \%$ of the students are said that they are strongly agreed with the question that the links given on the VU Mobile LMS App are easily accessible, $52.5 \%$ are agreed while $7 \%$ are stand neutral on the question that the links given on the VU Mobile LMS App are easily accessible meanwhile 0\% of the students are showed disagreement with the said question.

Regarding the impact of VU Mobile App towards Student Learning 143 students said that they are strongly agreed and can easily post an MDB, through VU LMS Mobile App, 48 are agreed while 9 students are disagreed with the question. The results also illustrates that 177 of students are strongly agreed that compare to web LMS, VU LMS Mobile App Provide easy access to my courses, 20 are agreed are 9 are neutral with the question. While 33 students are strongly agreed that VU LMS Mobile App gives a prompt message of any Assignment, Quiz and GDB announcement. We can clearly observe that impact is very high of the mobile app of the virtual university.

\section{CONCLUSION}

This research highlighted the usage, design and impact of Mobile LMS application on learning of VUP students. This study concludes that virtual university mobile application is an effective resource for students learning considering the distance learning-based environment. It is designed to cope with the learning needs of students and to provide them with an easy access to the course activities and respective course contents. Moreover, the students can ubiquitously access the application. Students have shown their satisfaction with the application and have recommended that links to other reading contents need to be provided in the interface to make their courses more interesting for learning.

\section{REFERENCES}

[1]. Resta, Paul E., ed. Information and communication technologies in teacher education: A planning guide. UNESCO, 2002.

[2]. Wani, Hilal Ahmad. "The relevance of elearning in higher education." ATIKAN 3, no. 2 (2013).

[3]. Lonn, Steven, Stephanie D. Teasley, and Andrew E. Krumm. "Who needs to do what where?: Using learning management systems on residential vs. commuter campuses." Computers \& Education 56, no. 3 (2011): 642-649.

[4]. Delfino, Manuela, Giuliana Dettori, and Valentina Lupi. "Task-based learning and ICT: creative activities in the context of a European project." eLearning Papers 16 (2009): 1-11.
[5]. Annetta, Leonard A., Meng-Tzu Cheng, and Shawn Holmes. "Assessing twenty-first century skills through a teacher created video game for high school biology students." Research in Science \& Technological Education 28, no. 2 (2010): 101-114.

[6]. Moll, Ian. "Curriculum responsiveness: The anatomy of a concept." Curriculum responsiveness: Case studies in higher education 1 (2004).

[7]. McQuiggan, Carol A. "Faculty development for online teaching as a catalyst for change." Journal of Asynchronous Learning Networks 16, no. 2 (2012): 27-61.

[8]. Beetham, Helen, and Rhona Sharpe, eds. Rethinking pedagogy for a digital age: Designing and delivering e-learning. routledge, 2007.

[9]. Moore, Michael G., and Melody M. Thompson. "The Effects of Distance Learning: A Summary of Literature. Research Monograph Number 2." (1990).

[10]. Harrati, Nouzha, Imed Bouchrika, and Zohra Mahfouf. "e-Learning: On the uptake of modern technologies for online education." In 2016 6th International Conference on Information Communication and Management (ICICM), pp. 162-166. IEEE, 2016.

[11]. Cheon, Jongpil, Sangno Lee, Steven M. Crooks, and Jaeki Song. "An investigation of mobile learning readiness in higher education based on the theory of planned behavior." Computers \& education 59, no. 3 (2012): 1054-1064.

[12]. Shawar, Bayan Abu. "Learning management system and its relationship with knowledge management." In Fourth international conference on intelligent computing and information systems, pp. 19-22. 2009.

[13]. Woodill, Gary. The mobile learning edge: Tools and technologies for developing your teams. New York: McGraw-Hill, 2011.

[14]. Han, Insook, and Seungyeon Han. "Adoption of the mobile campus in a cyber university." International Review of Research in Open and Distributed Learning 15, no. 6 (2014): 237-256.

[15]. Han, Insook, and Won Sug Shin. "The use of a mobile learning management system and academic achievement of online students." Computers \& Education 102 (2016): 79-89.

[16]. Silva, Ana Alexandra, Fernando Gomes, and Maria João Marçalo. "20 Years of Eurocall: Learning from the Past, Looking to the future." (2013).

[17]. Minhas, Shahid, Masroor Ahmed, and Qazi Farman Ullah. "Usage of Whatsapp: 
A Study of University of Peshawar, Pakistan." International Journal of Humanities and Social Science Invention 5, no. 7 (2016): 71-73.

[18]. Poonam Mote et al., International Journal of Advanced Trends in Computer Science and Engineering, 1 (2), May - June, 2012 , $67-72$

[19]. Minhas, Shahid, Tasaddaq Hussain, Abdul ghani, and Kiran sajid. "Exploring students online learning: a study of zoom application." Gazi University Journal of Science, 34 (02):(2021). https://doi: 10.35378 /gujs.691705 